\title{
On Chinese-English Translation Strategies of Biopharmaceutical Corporate Profiles Guided by Adaptation Theory
}

\author{
CHEN Ling \\ School of Foreign Languages, Quanzhou Normal University, Quanzhou, Fujian, China
}

WANG Caiying

School of Foreign Languages, Quanzhou Normal University, Quanzhou, Fujian, China

Received: June 8, $2021 \quad$ Accepted: August 30, $2021 \quad$ Published: September 19, 2021

doi: 10.5296/jsss.v8i2.19022ＵRL: https://doi.org/10.5296/jsss.v8i2.19022

\begin{abstract}
With the closer economic ties between countries and the spread of epidemics such as COVID-19, Chinese pharmaceutical enterprises have a potential international market. The quality of the English translation of pharmaceutical company profiles is of great significance to the development of international market and human health. Compared with 8 Chinese and 8 English pharmaceutical company profiles, there are significant different focuses. Besides the basic information, Chinese pharmaceutical company profiles stress the history and awards of the companies, while English pharmaceutical company profiles are centered on the effective information. The existing C-E translation problems lie in word-for-word translation, lack of logic between sentences or text and redundancy. Guided by adaptation theory, the following conclusions are drawn: on syntax level, when translating, the translator should apply the methods of creative translation, clarify the logical relationship between clauses, adjust the word order of sentences and appropriately add logical conjunctions. On discourse level, the translator can use creative translation - recompose the information of the profiles. Besides, we should emphasize the company's care for life and health. Only in this way can contextual relations and linguistic structure be adapted. I hope it will be helpful to the English translation of the profiles of Chinese pharmaceutical enterprises.
\end{abstract}

Keywords: Adaptation Theory, Pharmaceutical company's profile, Word cloud map, Translation strategies 


\section{Introduction}

Now the world is plagued by COVID_ 19, pharmaceutical companies have a huge potential international market. However, if Chinese enterprises want to enter international markets successfully, they must first improve their own international visibility and the trust of potential consumers and partners. Therefore a good company profile is conductive to achieving the aforementioned purposes. Corporate profile is just like the visiting card of a company. It not only shows the image of the company, but also stimulates their desires to purchase or cooperate, which determines the publicity effect and even the economic benefits of the company to a certain extent. But at present, there are various problems in the translation of pharmaceutical enterprise profiles, which makes it difficult to play its due role. Adaptation theory is a guide to the choice of language when translating. Based on the previous research results and guided by the Adaptation theory, this paper puts forward corresponding and feasible English translation strategies for the profiles of pharmaceutical companies, so as to promote Chinese companies to "go global" better.

\section{Literature Review}

\subsection{Overview of Enterprise Translation Research}

In the early 1990s, Liu Xiangang first proposed to conduct theoretical research on enterprise translation in China, and repeatedly called for the establishment of a specialized discipline to conduct research on it. By publishing articles, he demonstrated the necessity and possibility of establishing enterprise translation studies, and set up a basic framework, which played an significant role in promoting the establishment of enterprise translation studies afterwards. Led by him, enterprise translation began to receive more and more scholars' attention, and gradually developed into a new sub-discipline of translation. Some scholars conduct research from the nature of enterprise translation. For example, Li Guishan (2002) demonstrated that the most important feature of enterprise translation should be utilitarianism by showing the characteristics and concrete performance of it. By arguing that the knowledge, specialized vocabulary and customary expressions required for translation are different from those of technical English, he contended that corporate translation should not be the same as technical translation. It also pointed out the necessity and importance for enterprises to have and cultivate their own specialized translation teams. All these studies have enhanced the guiding significance of adaptation theory to corporate translation practice.

Some scholars use other theories to guide the practice of corporate translation. For example, Wen and Chen (2003) used the reception aesthetics theory and single out some translation suggestions. Xu Jianzhong's book Translation Practices for Industrial and Commercial Enterprises introduces the process of enterprise translation development to industry recognition, analyzes the characteristics of corporate translation, summarizes the principles of corporate translation, and finally proposes some translation strategies, which has far-reaching implications for the development of enterprise translation studies (Xu, 2002). Lv Lixian introduced the concept of parallel text and sorted out translation strategies according to the differences in structure, culture and language style between Chinese and English texts (Lv, 2016). 


\subsection{Shortcomings of Translation Studies on Corporate Profiles}

Although more and more scholars have conducted translation studies of corporate profiles on the basis of corporate translation studies, for example, Jia Heping proposed the strategies of deletion, omission and rewriting by analyzing the linguistic, pragmatic and cultural translation errors in corporate profiles (Jia, 2014). However, most of them are based on Functional Equivalence Theory or Skopos Theory. For example, Huang Shihui, guided by Skopos Theory, summarized that the translation of company profile should follow the principle of purpose, the principle of translator's subjectivity and the principle of reader-oriented (Huang, 2012).

As we all know, the terminology and jargon of different industries varies from industry to industry. Accordingly, the terminology and emphasis in the profiles of different companies may also vary. Therefore, more research is in line with the need. Starting from Skopos Theory, Xie Li analyzes the discourse, pragmatic, and cultural problems in Henan Province's enterprise profiles and the causes behind them, and proposes corresponding translation strategies from the three aspects of translators, companies and society. Studies focusing on the translation of enterprise profiles of a certain type or region, are more in line with the current needs, but not in large numbers (Xie, 2014).

Among them, few scholars have studied the English translation of pharmaceutical enterprise profiles. For example, Chen Kailun summarized three common mistakes in the English translation of pharmaceutical company introductions based on the Reception Theory and with the target language readers as the center. He proposed to improve the acceptability of pharmaceutical company profiles by strictly selecting medical terms, appropriately supplementing them, omitting useless information, classifying main points, and highlighting key points. It has a certain guiding significance for the English translation of pharmaceutical company profiles, but there is still a broad research space to be developed (Chen, 2016).

In recent years, the impact of epidemics such as Ebola and COVID-19 has raised more concerns about life and health. Pharmaceutical companies have a broader market. Appropriate English translations of company profiles are helpful for pharmaceutical enterprises to go international, expand the market and strengthen communication.

\section{Theoretical Framework}

Adaptation Theory not only explains language phenomena at the macro level of cognitive culture and society, but also conducts research on selection and usage of language at all levels of language structure.

\subsection{Core Concepts of Adaptation Theory}

Verschueren believes that language has variability, negotiability, and adaptability. Variability means that language can be chosen. Negotiability means that the language can be chosen flexibly, rather than being made mechanically in accordance with certain formalities or strict rules. Adaptability refers to the flexibility of language users to adapt from the various possibilities available to them in order to meet the needs of communication. Variability and 
negotiability provide possibilities and methods for language selection. Adaptability can only be achieved on the basis of variability and negotiability. Adaptability, the core of the language use process, is the ultimate goal to be achieved in language use. These three characteristics are conducive to solving the translation problems such as the translatability (Yang, 2005).

\subsection{The Research Perspective of Adaptation Theory}

Verschueren put forward Adaptation Theory from four aspects: context, linguistic structure, translator, and the process of adaptation (Verschueren, 2005). This paper mainly introduces the contextual correlates of adaptability and structural objects of adaptability.

\subsubsection{Contextual Correlates of Adaptability}

Context refers to the environment in which language is used for communication. It is composed of a series of factors that adapt to discourse and influence the processing of discourse. It can be roughly divided into two parts. One is the language context, and the other is the communicative context.

The communicative context consists of mental, social, physical world and communicative parties. In the communicative context, communicative parties play an important role in the production and understanding of discourse (He, 2007).

The importance of communicative parties in communication is not only reflected in their social roles, but also in their choice of contextual components. The number and category of speakers have a direct impact on the expression of utterances and the comprehension of the interpreter. Whether the speaker is the only source or one of the sources of information is directly reflected in his choice of language (He, 2007). Next, the number of utterers also affects the discourse (He, 2007). Language users are not limited to the two parties of the conversation, but also to others related to the content of the conversation (Chen, 2001).

The physical world mainly refers to the influence of time and space on language choice. It consists of factors such as the time of the event, the time of the speech, the time of the reference, the position of the communicative parties in the physical world, the physical appearance and characteristics (Yang, 2006). A typical example is that we choose different greetings as the time of day and night changes.

The social world means that the choice of language is restricted by various principles and norms in social settings or institutions and social environments. In other words, the choice of language must conform to the communicative norms of the social settings or institution, the social environment and the linguistic society (Yan, 2006). The number and variety of social factors that need to be taken into account make adaptation more complex and dynamic.

The mental world involves the cognitive, emotional and other psychological states of the communicator, such as personality, desire, intention, motivation, concept, etc. The language selection process of one party in communication is a dynamic process of adapting to one's own and the other party's psychological world (Yang, 2006).

Linguistic context consists of cohesion, intertextuality and sequencing. Cohesion refers to the 
realization of semantic relevance through methods such as reference, connection, repetition, omission, repetition, and contrast. Intertextuality refers to the restriction and influence of factors such as situation, style, theme on a text. Sequencing refers to the ordering of discourse to reflect the logical relationship of the original language (Yang, 2006).

\subsubsection{Structural Objects of Adaptability}

Language selection can occur at any level of its structure. First of all, it can occur on the symbol system, which includes both linguistic symbols in native or foreign language and nonverbal symbols such as gestures, eyes' expressions and so on. Then we choose oral or written channels of communication. Depending on who we communicate with and where we communicate, we choose different codes of speech such as dialects, jargon, idiomatic expressions. We also choose the degree of formality of the language according to factors such as the degree of formality of the conversation and the topic of discussion. Language features can also be affected by speech events. At the level of discourse, the structure and characteristics of the discourse are analyzed according to the category to which it belongs. At the syntactic level, attention should be paid to the choice of referential relations, discourse types, grammatical relations and so on. In terms of vocabulary, it is necessary to choose the lexical nature, meaning, and function of words and so on. Finally, attention needs to be paid to the selection of phonological features such as intonation and rhyme (He, 2007).

The construction principle of discourse depends on grammatical rules at the level of sentence, and at the level of the paragraph, it mainly takes the coherence and relevance of meaning as the principle (Ge, 2002). Through the adaptation of these choices, the target text is made to be close to the source language at all levels of language structure in order to achieve the purpose of communication.

\subsection{Adaptation Theory and Translation Studies}

Adaptation Theory not only explains language phenomena at the macro level of cognitive culture and society, but also conducts research on selection and usage of language at all levels. Therefore, the translator's translation activities can be regarded as his language choice based on the purpose of different communicative activities and at different levels of consciousness. Language choice can be either conscious or unconscious, and it can be influenced internally or externally. The use of language is equivalent to choices being made constantly (Verschueren, 1999).

In addition to the two-way communication characteristics of general communicative behavior, translation also has its uniqueness in time and space. The communication between the translator and the readers is not instantaneous in time and is dislocated in space (Chen, 2006).

Adaptation Theory fills the gap in translation studies in the previous analysis of the translator's transformation process. The proposal of Adaptation Theory has also affected the academic discussion on translation standards, making the principle of translation equivalence difficult to hold (Chen, 2006).

In short, Adaptation Theory aims to make language choice in line with the object of 
communication, the environment of communication, and the purpose of communication in order to achieve successful cross-cultural communication, which is also the purpose of translation (Song, 2004).

\section{Research Method}

This study is conducted to understand the differences between Chinese and English pharmaceutical companies, hoping to shed some lights on the translation and publicity of Chinese pharmaceutical companies.

\subsection{Research Questions}

This paper will mainly examine the semantic, syntax and discourse characteristics of the corporate profile texts of Chinese and American pharmaceutical companies. We endeavor to answer the following questions:

What are the typical features in the corporate profiles of Chinese pharmaceutical companies?

What are the typical features contained in the corporate profile text of English pharmaceutical company? How is it different from that of Chinese pharmaceutical companies?

In view of the above differences, how to translate Chinese pharmaceutical companies' corporate profiles into English is the focus of this paper.

\subsection{Source of Corpora}

This paper builds two micro corpora from the company profiles on the websites of 8 famous pharmaceutical companies in English (Appendix I) and the company profiles of 8 famous pharmaceutical companies in China (Appendix II).

\subsection{Research Design}

First, we select 8 Chinese and English pharmaceutical companies as our Chinese and English corpora. We use word cloud map to analyze the word frequency, trying to find out the differences of Chinese and English pharmaceutical companies. We analyze sentences and texts with qualitative research methods, in the hope that we can find some dissimilarities in Chinese and English pharmaceutical companies.

\section{Analysis of Pharmaceutical Company Profiles}

\subsection{The Overview of Company Profiles}

The company profile has a variety of expressions such as "Enterprise Profile", "About us" and "Company Introduction". Broadly speaking, its content can be divided into four parts, namely, who we are, what we do, how we do and what results we have achieved.

In the section of "who we are", we can learn about company's nature, size, employees, development history etc.. In the section of "what we do", we can know about its business scope, main products, and R\&D capabilities. In the section of "how we do", we can learn about its history, such as its development purpose, development plan, future vision, etc. In the part of "what results we have achieved", we can learn about the operating status, sales 
performance, honors and so on.

These specific information can be based on the actual situation of the enterprise, and is not indispensable. Company profile is a material for external publicity, but also an intermediary for the company to communicate with potential customers or partners. A successful company profile can deliver the information to readers concisely, orderly, and accurately, and give full play to its promotional function.

\subsection{The Characteristics and Functions of Pharmaceutical Company's Profiles}

The style of company profile is practical, and its greatest feature is practicality. The main point is to convey some substantive information to readers (Tang, 2000).

As a kind of corporate publicity, the corporate profile is bound to convey a large amount of basic information to readers, win their trust and favor, and then establish and/or develop customer relationships or partnerships. Ultimately the goal of corporate economic gains will be achieved.

Secondly, the company profile also has the following three distinctive features: stylized article format, diversified expression techniques, accurate, concise and standardized language style (Tang, 2000).

The language of the company profile shows the characteristics of accuracy, conciseness and standardization. The Chinese characters 简介 (jianjie), which means "brief introduction", embodies the limit of length of this style. Only a concise statement can be presented within a limited space. Company profiles tend to use data, which is an accurate way of showing the scale and strength of the company.

The expression of its language presents diverse characteristics. Companies can show their rich cultural connotations and unique corporate culture through rhetorical techniques such as comparison, rhyme and quoting classic poems or allusions. At the same time, enterprises also use slogans to deepen the impression of the target readers.

Apart from the above-mentioned basic content and features of general corporate profiles, the profile of pharmaceutical companies also has some unique features. First of all, there are more professional terms in the profiles of pharmaceutical companies. Secondly, information on scientific research investment, talent team, R\&D bases, and projects under research take up a large proportion. Finally, pharmaceutical companies will definitely mention their contributions to society in their profiles to reflect their sense of social responsibility, such as donating funds to social public welfare undertakings including poverty alleviation, education assistance and assistance to the vulnerable groups.

Peter Newmark classified text into expressive text, informative text and vocative text according to the function of language and the purpose. Most texts have more than one type of functions. In general, there may be several functions in a particular text, one or two of which play a leading role, while the others play a supporting role. Enterprise profiles are actually a mixture of three types, with information and vocative functions dominating, followed by the expressive function. 


\section{MInstitute ${ }^{\text {Mink }}$}

The core of informative text is the authenticity of the content, which reflects the objective facts to achieve the purpose of conveying information (Newmark, 2001).

The purpose of corporate profile is to provide the audience with the basic information about the enterprise, such as products and services, brands and advantages, so that the audience can have a comprehensive understanding of the enterprise in a short time.

\subsection{Contrast Between Chinese and English Pharmaceutical Company Profiles}

Chinese and English pharmaceutical corporate profiles are presented in the forms of different languages. Therefore, the content is more or less the same. As a kind of corporate publicity materials, both of them serve the purpose of corporate publicity and have the function of information transmission. However, there are inevitably some differences between Chinese and English due to different language, culture and context. Therefore, there are certain differences in words, sentences and text, such as the length of the content, the location of similar information, the language style, and the constituent elements of sentences.

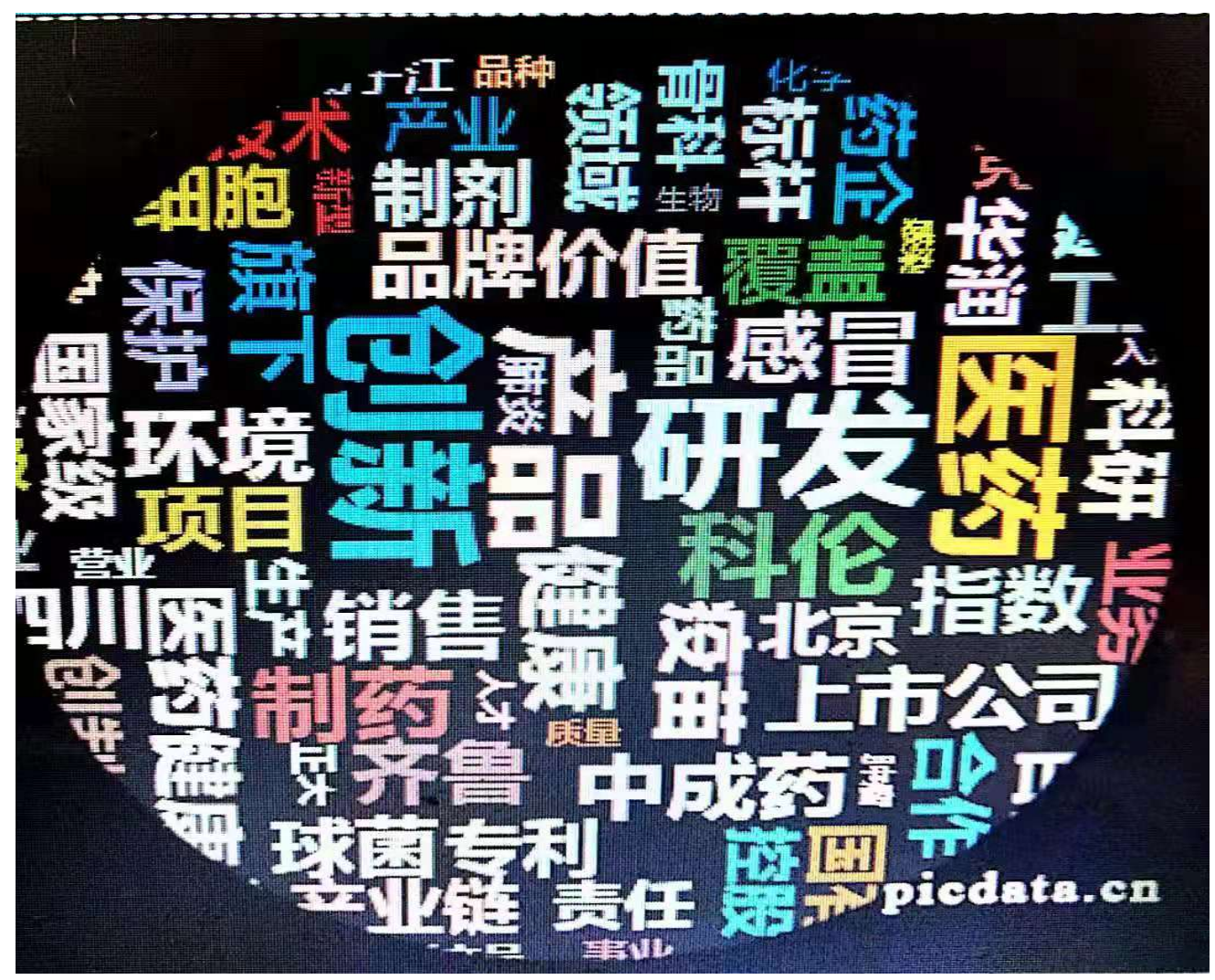

Figure 1. Word cloud map of 8 Chinese pharmaceutical company profiles 


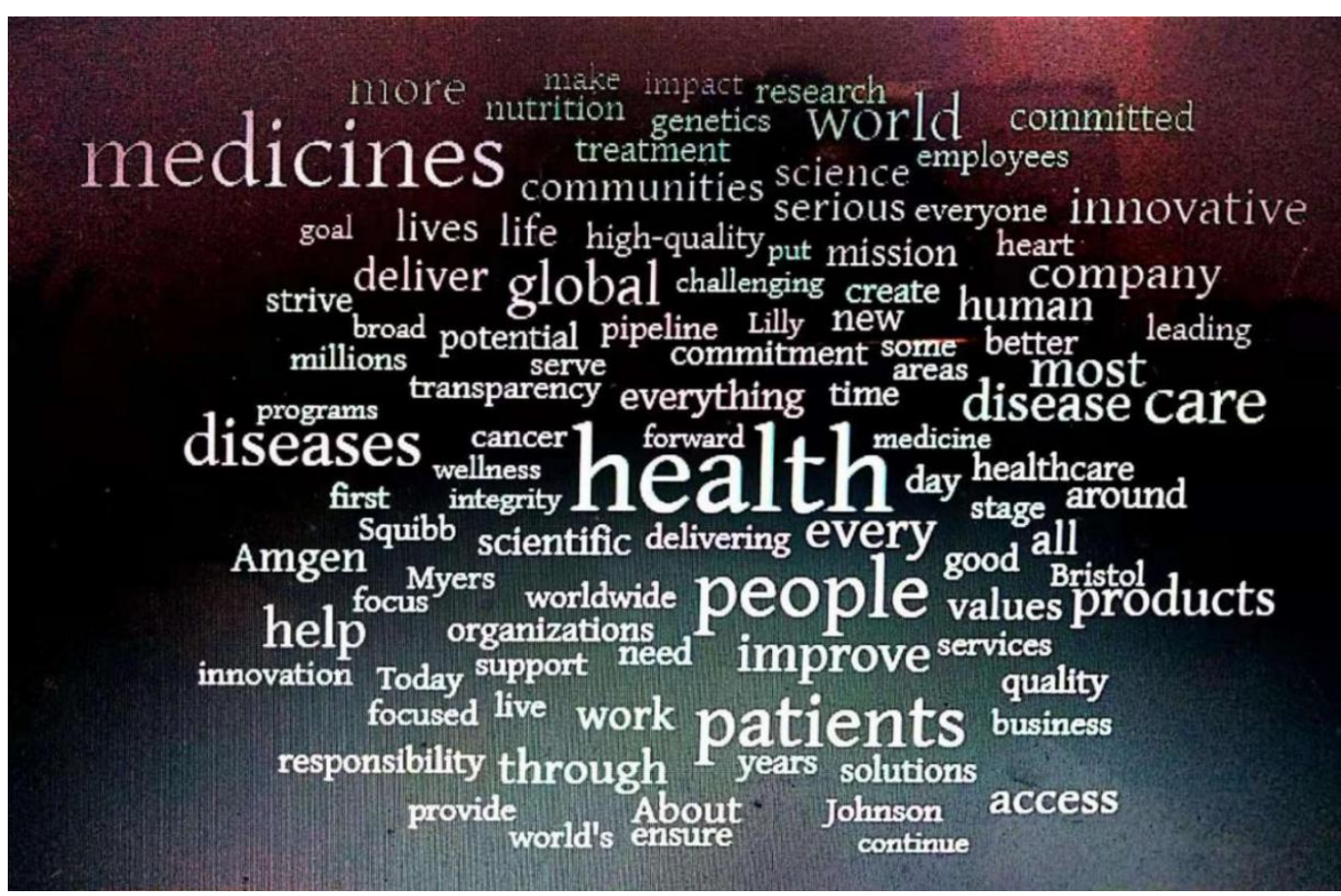

Figure 2. Word cloud map of 8 foreign pharmaceutical company profiles

By collecting the profiles of 8 (Note 1) Chinese and foreign pharmaceutical company profiles respectively (see Appendix I and II), the corresponding word cloud maps were created (see the above Figure 1 and Figure 2). From the above figures, we can see that the word "health" is given the first priority and appears most frequently in foreign pharmaceutical companies' profiles, followed by "medicine", "people", "patients", "disease", and "care". In addition, these frequent words are nouns. This shows that they focus more on the concern of people's health. However, the most frequent words in the Chinese company profiles are “研发 (yanfa)”, “创新 (chuangxin)”, “医药 (yiyao)”, “产品 (chanpin)”. This shows that the company focuses on the R\&D aspect and tries to show its strength. In Chinese, verbs, such as “研发 (yanfa)”, “创新 (chuangxin)” and “制药 (zhiyao)” are more common.

There are a wealth of four-character chain structures, such as “不忘初心, 牢记使命, 砥砺奋 进 (bu wang chuxin,laoji shiming dili fenjin)" in Chinese pharmaceutical company profiles, which also can be found in the eight profiles in Appendix II.

On syntactic level, many sentences in Chinese corporate profiles have a more fixed expression. In terms of rhetorical devices, parallelism, metaphor and quotation are often seen.

\section{Example 1:}

ST: 齐鲁制药以维护人类健康为宗旨, 以满足社会需求为己任, 以先进的科学技术为依 托, 致力于研制开发治疗常见病、多发病及其它多种严重危害人类健康疾病的药物。 (http://m.qilu-pharma.com/intro/1.html)

As in the Example 1, the underlined part is a very common sentence structure in Chinese 
profiles. However, the English syntax, on the other hand, is more flexible and less likely to see such fixed expressions.

Series verb constructions and long sentences are ubiquitous in Chinese corporate profiles, and most of the paragraphs contain only one sentence, while short sentences is common in English pharmaceutical company profiles. Furthermore, "We" is frequently used as the subjects in foreign pharmaceutical company profiles.

On discourse level, the corporate profiles in English are short in length. The eight profiles of foreign pharmaceutical companies collected were less than 500 words in total, five of which were less than 300, while the Chinese profiles were all long. Five of the eight have more than 800 words, and three of them even exceed 1100 .

Besides, subheadings are commonly-used in foreign pharmaceutical company profiles, and seven of the collected ones is comprised of several subheadings.

\section{Applying Adaptation Theory to Translate Pharmaceutical Company's Profiles}

\subsection{Syntactic Level}

To understand Chinese sentence requires a certain ability to analyze and understand the context, because some sentences are loose without logical conjunctions. However, English emphasizes logic and often uses logical conjunctions to express the internal logic of the text. When translating, we need integrate the sentences, clarify the logical relationship between them, then choose the appropriate logical connectives, and adjust the order if necessary. Only after understanding the semantic relationship and figuring out the contextual logic can we achieve compliance with sequencing.

\section{Example 2:}

ST: 重庆智飞生物制品股份有限公司 2002 年投入生物制品行业, 注册资金 16 亿元，现 有员工近 3000 人, 资产 136 亿元, 2019 年实现营业收入 105.9 亿元。(重庆智飞生物制 品股份有限公司 http://www.zhifeishengwu.com/)

TT: Chongqing Zhifei Biological Products Co., Ltd. ("Zhifei” or "the Company" for short) has its presence in biological product industry in 2002. The Company achieved an operating income of RMB10.59 billion in 2019 with the support of its nearly 3,000 employees based on its registered capital of RMB1.6 billion and total assets of RMB13.6 billion. (http://en.zhifeishengwu.com/about/zfgk/)

The logical relationship of underlined sentence in the Example 2 is hard to be seen literally. But from the English translation, the translator shows that the business revenue is realized on the basis of registered capital, employees and assets, which realizes the adaptation to the language structure of the target language.

It is also important to pay attention to the use of deduction within the sentence.

\section{Example 3:}

ST: 科伦是一家年销售收入超过 400 亿元的高度专业化创新型医药集团, 包括四川科伦 
药业股份有限公司、四川科伦药物研究院有限公司、Klus Pharma Inc. (美国科伦)、科伦 KAZ 药业有限责任公司(哈萨克斯坦科伦)、四川科伦医药贸易有限公司等海内外 100 余 家企业。(四川科伦药业股份有限公司 http://www.kelun.com/intro/1.html)

TT: Kelun is a highly specialized innovative pharmaceutical group with annual sales revenue over 40 billion RMB, including more than 100 enterprises at home and abroad, Sichuan Kelun Pharmaceutical Co., Ltd; Sichuan Kelun Drug Research Institute Co., Ltd; Klus Pharma Inc. (Kelun, USA), Kelun KAZ Pharmaceutical Co., Ltd (Kelun, Kazakhstan); Sichuan Kelun Medicine Trade Co., Ltd, etc. (http://en.kelun.com/intro/1.html)

The Chinese profile tends to list facts first and then summarize them. In English, deduction structure is often used. Therefore, when translating, we can insert a general phrase(including more than 100 enterprises at home and abroad) like Example3, which not only reflects the logic and conforms to the language structure of English, but also leaves the reader the choice of whether they need to continue reading in details.

\subsection{Discourse Level}

As mentioned above, of the eight collected foreign pharmaceutical company profiles, seven categorized the information and preceded the paragraphs with subheadings. Roughly, there are sections on leaders, values, culture, and history. Each section focuses on one topic. This not only reflects the hierarchy and intuition of the text, but also provides the reader with the convenience of selecting content of interest to them for further understanding based on the headings. In contrast, only one of the eight Chinese company did so, which are influenced by the Chinese language,culture or contexts.

This structure, in most cases, does not conform to the linguistic expression habits of the target language and does not adapt to its linguistic structure. So we should first classify the overall content, extract the core points, and present them in the form of subheadings, and then arrange them according to the importance of the content.

In the previous chapter, we compared the word frequency differences between Chinese and foreign pharmaceutical company profiles and found that the profiles of foreign pharmaceutical companies emphasize more on humanistic concerns of the company. All of the eight foreign profiles have similar expressions. This reflects the intertextuality of the discussed topics.

\section{Example 4:}

Bristol Myers Squibb is a global biopharmaceutical company whose mission is to discover, develop and deliver innovative medicines that help patients prevail over serious diseases. (https://www.bms.com/about-us/our-company.html)

Example $_{4}$ is the first sentence in Bristol Myers Squibb's profile. Through this sentence, we can not only feel the humanistic care of the company, but also its willingness to innovate in pharmaceuticals and the confidence to overcome diseases, which skillfully win the readers' favor. Similar expressions account for a relatively large proportion of English pharmaceutical company profiles. This corresponds to the internal requirements of the text of the 
pharmaceutical industry, which is closely related to the safety and health of human life.

However, the description of this type of information in the Chinese company profile is only one or two sentences. Some are even deleted directly in the English translation. This fails to be responsive to the language context, which is not conducive to attracting foreign potential customers. Therefore, when translating them, we should increase the length appropriately, pay attention to reflect the enterprise's concern for health and life, so that this key point can be highlighted.

On the contrary, Chinese companies often enumerate the honors they have received in their profiles to highlight the strengths and popularity of the company. Indeed, awards can show the strong points of the enterprise to a certain extent. However, this also led to the translation misconception that many enterprises blindly and literally translate all the awards they have received. The word cloud map in the previous chapter also shows that award-related words appear very rare in the profiles of foreign pharmaceutical companies. In fact, most foreign companies take customer reputation as the criterion to judge the strength of the company. Besides, many provincial awards are not as convincing as one might think. Affected by differences in social environments, it is difficult for foreign readers to understand the meaning of awards. Therefore, for the translation of awards and honors, we can choose one or two awards with international popularity and recognition for translation.

\section{Example 5:}

ST: 2017 年, 科伦位居中国制造业 500 强第 155 位, 综合实力进入中国医药工业前三甲。 2018 年，科伦凭借大容量注射剂的全球优势获评制造业单项冠军示范企业。2020 年, 科伦获评国家技术创新示范企业。（四川科伦药业股份有限公司 http://www.kelun.com/intro/1.html)

TT: In 2017, Kelun ranked 155th in China's top 500 manufacturing enterprises, and comprehensive strength ranked top three in China's pharmaceutical industry. (http://en.kelun.com/intro/1.html)

In Examples, the English translation of Kelun's profile only translates its ranking in the whole Chinese industry. This kind of industry ranking is far more convincing for foreign readers than the latter two awards. For the latter two awards, which are unfamiliar to foreign readers, the translator directly adopted the provincial translation method. It is worth learning how to respond to the worldwide readers.

\section{Conclusion}

Firstly, the content, core concepts and research perspectives of Adaptation Theory are introduced. Then through the collection and analysis of the translation of pharmaceutical company profiles, the characteristics and functions of the company profile are summarized. Then, I collected eight Chinese and foreign pharmaceutical company profiles respectively and made word cloud maps to analyze the differences in word frequency and then the comparison and contrast on syntax and discourse level are analyzed.

The result shows: 1) On lexical level, more attention has been paid on people's health and 
medicine in English pharmaceutical company profiles. However, Chinese companies focus on the R\&D aspect and show three strengths. 2) On syntactic level, fixed expression,series verb constructions, rhetorical devices and long sentences are apt to be used in Chinese pharmaceutical company profiles, but short sentences and the subject "We" are given the first priority in English pharmaceutical company profiles. 3) On discourse level, English profiles are shorter in length than Chinese ones. Subheadings are commonly-used in foreign pharmaceutical company profiles, while subheadings are scarcely used in Chinese ones.In addition, the honors to highlight the strengths and popularity of the company are listed in Chinese pharmaceutical company profiles, while they seldom appear in the profiles of foreign pharmaceutical companies.

Based on the findings, more translation methods should be applied to translate four -character chain phrases in the profiles of Chinese pharmaceutical companies. In addition, we should emphasize the company's care for life and health. In terms of syntax, attention should be paid to clarify the logical relationship between sentences, change long sentences into short ones, add logical conjunctions, adjust the order of words, and also using creative translation to achieve adaptation of the language structure and language context of the target language. In terms of discourse, we should first classify the information in the text, and then extract the main points as subheadings. If necessary, some redundant information can be deleted. The information of honors can also be omitted or only retained several convincing ones.

This paper has certain practical significance. At present, there are few related researches on the translation of pharmaceutical company profiles. Pharmaceutical companies currently have the potential to enter the international market. Appropriate translation of company profile is helpful for domestic and foreign enterprises to establish partnerships, so as to promote more in-depth exchanges and research in the field of medicine, and jointly promote the development of human health, which has certain practical significance and value.

However, this paper still has the following deficiencies to be improved. First of all, the number of analysis cases selected in this thesis is limited, with insufficient typicality and limited scope of application. Secondly, translation is a subject requiring profound cultural background and extensive knowledge, such as medical knowledge.

\section{Acknowledgement}

This article is supported by "On blending the information technology and English teaching" (FJJKXB19-545).

\section{References}

Chen, K. L. (2016). On the C-E Translation of Pharmaceutical Corporation Profile from the Perspective of Reception Theory. Fujian Normal University.

Chen, L. X. (2006). On Translation Studies from the Perspective of Pragmatic Adaptation Theory. Jiangxi Social Science, 11, 219-222.

Chen, X. H. (2001). On Context Adaptation in Translation. Journal of Hunan University (Social Science Edition), S2, 158-160. 
Ge, L. L. (2002). The Enlightenment of Adaptation Theory to Translation Studies_— on the Standards of Pragmatic Translation. Foreign Language Research, 3, 7-11.

Ge, L. L. (2005). Cultural Context Adaptation and Translation Decoding. Journal of Xi'an International Studies University, 1, 44-47.

He, Z. R. (2007). New Developments in Pragmatics:Relevance,Adaptation and Memetics. Shanghai: Shanghai Educational Publishing House.

Huang, S. H. (2012). The Translation of Corporate Profiles Based on Skopos Theory. Journal of Huaihai Institute of Technology, 17, 75-78.

Jia, H. P. (2014). On the Problems in the English Translation of Enterprise Profiles and the Countermeasures. China Business \& Trade, 15, 181-182.

Li, G. S. (2002). On the Utility of Enterprise Translation. Shanghai Journal of Translators for Science and Technology, 3, 28-30.

Lv, L. X. (2016). On Chinese-English Translation Strategies of Enterprise Profiles from the Perspective of Parallel Texts. Journal of Changzhou Institute of Technology (Social Science Edition), 3, 62-66.

Newmark, P. (2001). Approaches to Translation. Shanghai: Shanghai Foreign Language Education Press.

Song, Z. P. (2004). Translation: A Continuous Process of Choice Making for the Purpose of Adaptation. Chinese Translators Journal, 2, 21-25.

Tang, F. H. (2000). On the Stylistic Features and English Translation Skills of Enterprise Publicity Materials. Chinese Science \& Technology Translators Journal, 1, 26-29.

Verschueren, J. (1999). Understanding Pragmatics. London \& New York: Oxford University Press.

Verschueren, J. (2005). Handbook of Pragmatics. Amsterdam Philadelphia: John Benjamins.

Wen, J., \& Chen, M. (20003). On the Translation Strategies of Enterprise Translation from the Recipient Theory. Shanghai Journal of Translators for Science and Technology, 2, 17-19.

Xie, L. (2014). An Analysis of Company Profile Translation in Henan Province from Skopos Theory. Journal of Bijie University, 9, 115-119.

Xu, J. Z. (2002). Translation Practice for Industrial and Commercial Enterprises. Beijing: China Translation \& Publishing Corporation.

Yang, J. F. (2005). Context Adaptation and Pragmatic Translation. Foreign Language and Their Teaching, 11, 51-54.

Yang, M. (2006). Context Adaptation and Cultural Translation. Foreign Language Education, 3, 87-89. 


\section{Note}

Note 1. 8 Chinese pharmaceutical companies and 8 foreign pharmaceutical companies

\section{Appendix}

Appendix I English Pharmaceutical Company Profiles

https://www.msd.com/company-overview/

\section{About our company}

We invent for a more hopeful future.

We aspire to be the premier research-intensive biopharmaceutical company in the world.

For 130 years, MSD has been inventing for life, bringing forward medicines and vaccines for many of the world's most challenging diseases in pursuit of our mission to save and improve lives.

We demonstrate our commitment to patients and population health by increasing access to health care through far-reaching policies, programs and partnerships.

Today, we continue to be at the forefront of research to prevent and treat diseases that threaten people and animals - including cancer, infectious diseases, such as HIV and Ebola, and emerging animal diseases.

Responsibility

The heart of our mission

We believe corporate responsibility is about our health, social, environmental and economic impact on people and communities around the world.

Leadership

The team that guides our work.

Our leaders focus on our mission to save and improve lives around the world. This is the foundation of everything we do.

Our values

Our values represent the very core of our character. They guide every decision and action we take.

Patients first

We are all accountable for delivering high-quality products and services. We aspire to improve the health and wellness of people and animals worldwide and to expand access to our medicines and vaccines. All of our actions must be measured against our responsibility to those who use or need our products.

Culture \& values 
Our values are driven by a desire to improve life.

We've built a culture that embraces scientific excellence, operates with the highest standards of integrity, expands access to our products and employs a diverse workforce that values collaboration.

https://www.gsk.com/en-gb/about-us/

\section{About us}

We are a science-led global healthcare company with a special purpose: to help people do more, feel better, live longer.

We have three global businesses that research, develop and manufacture innovative pharmaceutical medicines, vaccines and consumer healthcare products. Every day, we help improve the health of millions of people around the world.

Our goal is to be one of the world's most innovative, best performing and trusted healthcare companies.

Our values and expectations are at the heart of everything we do - so that together we can deliver extraordinary impact for our patients and consumers and make GSK a brilliant place to work.

Our values are Patient focus, Transparency, Respect, Integrity.

Our expectations are Courage, Accountability, Development, Teamwork.

What we do

We aim to bring differentiated, high-quality and needed healthcare products to as many people as possible, with our 3 global businesses, scientific and technical know-how and talented people.

How we do it

Everyone at GSK is focused on our three long-term priorities-Innovation, Performance, Trust, all powered by our performance-focused culture.

https://www.jnj.com/about-jnj

About Johnson \& Johnson

At Johnson \& Johnson, we believe good health is the foundation of vibrant lives, thriving communities and forward progress. That's why for more than 130 years, we have aimed to keep people well at every age and every stage of life. Today, as the world's largest and most broadly based healthcare company, we are committed to using our reach and size for good. We strive to improve access and affordability, create healthier communities, and put a healthy mind, body and environment within reach of everyone, everywhere.

Every day, our more than 130,000 employees across the world are blending heart, science and ingenuity to profoundly change the trajectory of health for humanity. 
J\&J Our Story

We've been caring for people for more than 130 years. Learn more about the history of our company and our people.

Our Commitment to Our People

Diversity is a core part of our culture.

We've championed women at work, at home and across the world since 1886.

Our Commitment to Innovation

We help entrepreneurs realize their dreams of creating healthcare solutions.

Stories of Innovation

6 Next Gen Healthcare Innovations Designed to Boost Your Mind, Body and Soul

The Johnson \& Johnson Under 40 to Watch List: 6 Young Trailblazing Scientists

3 Groundbreaking Ways Researchers Are Rethinking Alzheimer's Disease

Johnson \& Johnson Debuts Its New Center for Device Innovation at Texas Medical Center

https://www.lilly.com/who-we-are/about-lilly

About Lilly

Lilly was founded in 1876 by Colonel Eli Lilly, a man committed to creating high-quality medicines that met real needs in an era of unreliable elixirs peddled by questionable characters. His charge to the generations of employees who have followed was this: "Take what you find here and make it better and better."

More than 140 years later, we remain committed to his vision through every aspect of our business and the people we serve starting with those who take our medicines, and extending to health care professionals, employees and the communities in which we live.

Lilly's purpose has never been more important.

When the COVID-19 pandemic shut down the world, Lilly teams jumped in to attack it with everything we could. After an extraordinary year of loss, sacrifice and progress, Lilly scientists and leaders reflect on our purpose and how it powered their urgency and passion to help. Learn more about our global response to COVID-19.

Lilly's Purpose

Lilly unites caring with discovery to create medicines that make life better for people around the world.

Three long-established core values guide all that we do at Lilly.

Integrity 
We conduct our business consistent with all applicable laws and are honest in our dealings with customers, employees, shareholders, partners, suppliers, competitors and the community.

Excellence

We pursue pharmaceutical innovation, provide high-quality products and strive to deliver superior business results.

Respect for People

We maintain an environment built on mutual respect, openness and individual integrity. This includes our concern for all people who touch or are touched by our company: customers, employees, shareholders, partners, suppliers and communities.

Discovery is our calling.

It's the spirit that has defined us since the day Colonel Eli Lilly opened the doors of our first laboratory in Indianapolis. Over 140 years and nearly 100 medicines later, we keep looking for the next great discovery and for even more ways to make life better for people around the world.

https://www.bms.com/about-us/our-company.html

\section{Our Company}

Bristol Myers Squibb is a global biopharmaceutical company whose mission is to discover, develop and deliver innovative medicines that help patients prevail over serious diseases.

At Bristol Myers Squibb, we believe in the power of science to address some of the most challenging diseases of our time. Our focus on these unmet needs comes during a remarkable time, when unprecedented scientific breakthroughs are advancing the treatment of disease as never before in human history.

We work every day to transform patients' lives through science. Each day, our employees around the world work together for patients - they are at the center of everything we do. They inspire us. They are the reason we come to work each day. We combine the agility of a biotech with the reach and resources of an established pharmaceutical company to create a global leading biopharma company powered by talented individuals who drive scientific innovation.

We are proud of the advancements we have made in oncology, hematology, immunology and cardiovascular disease, and we are dedicated to helping patients prevail over serious diseases through our diverse and promising pipelines and new scientific platforms.

As global citizens, we work sustainably and responsibly to create a positive impact in the communities where we live and work. We conduct our global business with the utmost integrity and transparency. We support programs, initiatives and organizations that help improve health, expand research opportunities, promote and expand STEM education and deliver basic human services to our communities. 
We know that our responsibility goes beyond medicine. We promote health equity globally and strive to increase access to life-saving medicines for populations disproportionately affected by serious diseases and conditions. We achieve this in part through the Bristol Myers Squibb Foundation, which supports community-based programs that promote cancer awareness, screening, care and support among high-risk populations.

Our Mission and Commitment

Bristol Myers Squibb is a global BioPharma company firmly focused on its mission to discover, develop and deliver innovative medicines to patients with serious diseases.

Leadership

Our culture of inclusion and strong commitment to patients starts at the top.

Governance

Everything we do is guided by our unwavering dedication to our Mission \& Commitment.

Principles

We believe that the priceless ingredient of every product we make is the integrity of its maker.

\section{Locations}

Find out more about specific Bristol Myers Squibb facilities in North America, Europe, Asia, Latin America.

Doing Business with Us

We do business with companies run by people from diverse backgrounds. Let's work together to create a positive impact on our patients and your business.

Achievements

Our focus is always on helping patients, but it's nice to be recognized for the work we do.

https://www.amgen.com/about

\section{About Amgen}

Amgen is committed to unlocking the potential of biology for patients suffering from serious illnesses by discovering, developing, manufacturing and delivering innovative human therapeutics. This approach begins by using tools like advanced human genetics to unravel the complexities of disease and understand the fundamentals of human biology.

Our belief - and the core of our strategy - is that innovative, highly differentiated medicines that provide large clinical benefits in addressing serious diseases are medicines that will not only help patients, but also will help reduce the social and economic burden of disease in society today.

Amgen focuses on areas of high unmet medical need and leverages its expertise to strive for 
solutions that improve health outcomes and dramatically improve people's lives. A biotechnology innovator since 1980, Amgen has grown to be one of the world's leading independent biotechnology companies, has reached millions of patients around the world and is developing a pipeline of medicines with breakaway potential.

\section{Innovative Medicines}

We have a presence in approximately 100 countries and regions worldwide and our innovative medicines have reached millions of people in the fight against serious illnesses. We focus on six therapeutic areas: cardiovascular disease, oncology, bone health, neuroscience, nephrology and inflammation. Our medicines typically address diseases for which there are limited treatment options, or they are medicines that provide a viable option to what is otherwise available.

\section{Transformative Research}

Understanding the fundamental biological mechanisms of disease is a defining feature of Amgen's discovery research efforts - and a major contributor to the development of Amgen's deep and broad pipeline of potential new medicines. Amgen's "biology first" approach permits its scientists to first explore the complex molecular pathways of disease before determining what type of medicine, or modality, is most likely to deliver optimal efficacy and safety. With the advances in human genetics, Amgen continues to shed new light on the molecular roots of disease. Amgen subsidiary deCODE Genetics, a global leader in human genetics, is a powerful differentiator, greatly improving how we identify and validate human disease targets.

\section{World-Class Biomanufacturing}

The treatment of millions of seriously ill patients worldwide depends on the safe and reliable production of biologic medicines, which are administered by injection or intravenously. A worldwide leader in biologics manufacturing, Amgen has an outstanding track record of reliably delivering high-quality medicines to patients who need them. Significant skill, experience, vigilance and commitment are critical to help ensure the quality of a biologic medicine each time a new batch is made. At Amgen, robust quality control and a reliable supply of medicines for patients are every bit as important as scientific innovation.

https://www.wyethnutrition.com/

\section{About Wyeth Nutrition}

\section{A Pioneering Spirit}

At Wyeth we were founded on an unwillingness to accept the status quo.

We have pioneered infant and young child nutrition since 1915, consistently delivering scientifically-advanced nutrition \& personalized solutions for pregnant women, infants and young kids.

Simply put, we never compromise in the pursuit of progress. That's because we serve the 
most uncompromising people in the world.

And we're proud to say it's helped move us all forward. Our relentless challenging of science for the past 100 years has led to some of the most significant breakthroughs in infant nutrition.

Our responsibility is not only to this generation of children, but to the generations to come, which is why our commitment to quality extends far beyond our products, to the communities we serve through our global and local initiatives.

We're not just nourishing children, we're nourishing the future.

https://www.abbott.com/about-abbott/who-we-are.html

WHO WE ARE

\section{LIVE YOUR BEST LIFE, NOW AND IN THE FUTURE}

We understand that the first step to living your best life is good health. Everything we make is designed to help you do just that. That's our commitment to building life-changing technologies that keep your heart healthy, nourish your body at every stage of life, help you feel and move better, and bring you information, medicines and breakthroughs to manage your health.

\section{ABBOTT AT A GLANCE}

We create breakthrough products - in diagnostics, medical devices, nutrition and branded generic pharmaceuticals - that help you, your family and your community lead healthier lives, full of unlimited possibilities. Today, 109,000 of us are working to make a lasting impact on health in the more than 160 countries we serve.

\section{DISCOVER OUR HISTORY OF INNOVATION}

For more than 130 years, we've put science and innovation to work-to create more possibilities for more people through the power of health. We adapt and respond quickly to changes in the world around us to deliver better solutions to help people live their best lives. 
Appendix II Chinese Pharmaceutical Company Profiles

http://www.sinobiopharm.com/index.html\#/about/introduce

中国生物制药有限公司及附属公司是中国领先的创新研究和研发驱动型医药集团, 业务 覆盖医药研发平台、智能化生产和强大销售体系全产业链。产品包括多种生物药和化学 药, 在肝病、肿瘤、心脑血管病、骨科、消化系统、抗感染及呼吸系统疾病等多个极具 潜力的治疗领域处于优势地位。

本公司于 2000 年在港交所上市, 2013 年入选 MSCI 全球标准指数之中国指数成份股; 2018 年入选恒生指数成份股; 2019 年入选恒生中国企业指数成分股; 2020 年入选恒生 沪深港通生物科技 50 指数成分股、恒生中国（香港上市） 25 指数。连续两年（2019、 2020 ）荣登美国权威杂志《制药经理人》发布的“全球制药企业 TOP50”。连续四年 （2016-2019）荣登《福布斯》（亚洲）「亚太最佳公司 50 强」。

中生制药核心企业正大天晴药业集团股份有限公司位列 2019 年中国化学制药行业工业 企业综合实力百强榜第 6 位, 北京泰德制药股份有限公司位列第 32 位、南京正大天晴 第 40 位、正大丰海第 74 位、正大制药 (青岛) 第 87 位。经过数年发展, 集团已经成 为引领中国医药技术和产业创新发展的重要力量。

本公司持续取得卓越成就和稳健发展, 与高度重视研发及创新密不可分: 坚持研发投入 和产品创新能力行业领先; 立足政策趋势, 围绕主营业务的关联拓展, 全面布局大健康 发展战略; 积极利用大数据、人工智能及科技金融等新技术和手段, 不断提升企业的管 理和研发、生产和行销效率。

中国生物制药将继承正大集团“利国、利民、利企业”的价值观、秉承“健康、快乐、长 寿”的使命, 立足自主创新, 引进全球创新技术, 巩固在中国市场的领先地位。望与有 识之士共享医药健康产业的发展成果, 鼎力合作、共赢未来!

http://www.zhifeishengwu.com/

重庆智飞生物制品股份有限公司 2002 年投入生物制品行业, 注册资金 16 亿元, 截至 2020 年 12 月 31 日公司有员工 3300 余人, 总资产 152 亿元, 2020 年实现营业收入 151.9 亿元。2010 年 9 月在深交所挂牌上市 (股票代码: 300122), 成为第一家在创业板上市 的民营疫苗企业, 旗下五家全资子公司及两家参股子公司, 其中北京智飞绿竹生物制药 有限公司 (简称“智飞绿竹”) 及安徽智飞龙科马生物制药有限公司 (简称“智飞龙科马”) 为高新技术企业。

智飞生物系一家集疫苗、生物制品的研发、生产、推广、销售、配送及进出口为一体的 生物高科技企业, 主营的人用疫苗为国家七大战略性新兴产业, 发展前景广阔。现在售 产品包括 ACYW135 群脑膜炎球菌多糖疫苗 (盟威克®)、A 群 C 群脑膜炎球菌多糖结

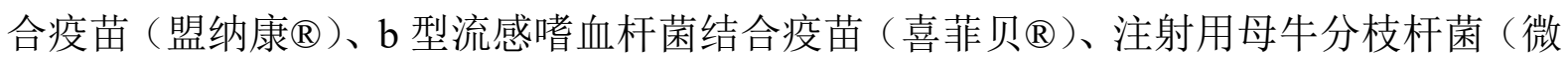
卡 $($ ) 、重组结核杆菌融合蛋白 ( EC 宜卡 $($ ) 、重组新型冠状病毒疫苗 (CHO 细胞) (智

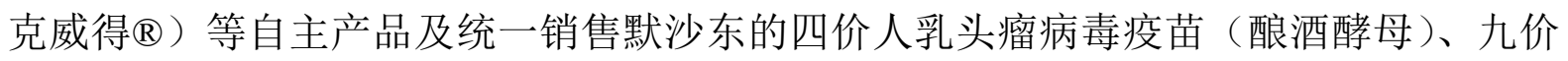
人乳头瘤病毒疫苗（酿酒酵母）、口服五价重配轮状病毒减毒活疫苗（Vero 细胞）、23 价肺炎球菌多糖疫苗、甲型肝炎灭活疫苗（人二倍体细胞）等所有进口疫苗。

公司通过“技术+市场” 的双轮驱动模式, 形成了市场、研发相互促进、互相转化的良好 


\section{MInstitute Macrothink $_{\text {Int }}$}

循环机制, 加速了疫苗产品从研发到实现市场价值转换的进程, 逐步形成了独具特色、 领先市场的核心竞争力。

公司组建了素质过硬的专家研发团队, 注重研发技术的引进和开发, 先后参与了科技部 863 计划“现代医学技术”项目、科技部重大新药创制、国家新药创制重大专项等 20 余 项重大项目。公司自主在研项目 27 项包括正在申请文号的、获得临床批件及临床前的 项目, 产品主要涉及预防肺结核、新冠、流脑、肺炎、流感、狂犬病、诺如病毒感染等 人用疫苗项目, 研发产品梯次结构清晰, 层次丰富。同时, 公司根据战略发展需要布局 大生物领域, 进入治疗性生物制品行业。此外, 公司构建了覆盖全面、深入终端的服务 网络, 为全国 31 个省、自治区、直辖市, 30000 余个基层卫生服务点（乡镇接种点、 社区门诊）提供持续、快捷、全面的优质服务。

公司自成立以来，始终本着“社会效益第一，企业效益第二”的企业宗旨及“六个第一， 六个第二”的核心价值观, 以提高国民预防健康意识为己任, 先后将十余种预防多种疾 病的疫苗产品导入市场, 为促进社会公共卫生事业的发展 起到一定的推动作用, 创造 了较好的社会效益。截止 2020 年, 公司已累计纳税超过 50 亿元。此外, 公司把社会公 益 事业作为回馈社会、承担社会责任的重要渠道, 近年累计捐款超过 3 亿元。公司经 过十余年的努力发展, 得到了社会各界的认可, 荣获全国抗击新冠肺炎疫情民营经济先 进个人、全国非公有制企业双强百佳党组织、全国“守合同重信 用”企业、全国商务诚 信试点企业、医药工业百强企业、中国 AAA 级信用企业等荣誉称号。

http://www.kelun.com/intro/1.html

科伦是一家年销售收入超过 400 亿元的高度专业化创新型医药集团, 包括四川科伦药业 股份有限公司、四川科伦药物研究院有限公司、Klus Pharma Inc.(美国科伦)、科伦 KAZ 药业有限责任公司(哈萨克斯坦科伦)、四川科伦医药贸易有限公司等海内外 100 余家企 业。2017 年, 科伦位居中国制造业 500 强第 155 位, 综合实力进入中国医药工业前三 甲。2018 年, 科伦凭借大容量注射剂的全球优势获评制造业单项冠军示范企业。

四川科伦药业股份有限公司于 2010 年 6 月在深圳证券交易所成功上市。甫一上市, 科 伦立即启动百亿产业投资计划, 开始实施“三发驱动、创新增长”的发展战略。第一台发 动机是通过持续的产业升级和品种结构调整, 保持科伦在输液领域的绝对领先地位; 第 二台发动机是通过对优质自然资源的创新性开发利用, 构建从中间体、原料药到制剂的 抗生素全产业链竞争优势; 第三台发动机是通过研发体系的建设和多元化的技术创新, 积累企业基业长青的终极驱动力量。

在输液领域, 科伦已经实现全面的产业升级, 具备高端制造和新型材料双重特点的赢利 能力, 占据了技术创新和质量标杆的战略高地。科伦建立了从药品的研究开发、生产制 造、物流转运直至终端使用的闭合式责任体系, 以确保产品质量安全, 主导产品已实现 批量出口, 在 40 多个国家和地区享有盛誉。科伦自主研发的可立袋®为国内外首创, 拥有二十多项专利, 荣获国家科学技术进步奖。它比传统输液具有更高的安全性和性价 比, 在降低能耗和环境保护方面也有巨大的应用价值, 代表着中国输液产品发展的方向, 深刻地改变了行业格局。

在基本完成输液领域的横向整合后, 科伦又启动了抗生素领域的纵向整合, 在全国进行 “抗生素全产业链”的战略性布局。公司衔枚西进，设立了伊犁川宁生物技术有限公司， 生产硫氰酸红霉素和头孢系列中间体。通过研发试验、升级优化、创新合作、引进国内 


\section{Ml Macrothink}

外先进技术设备, 川宁获批建设国家环境保护抗生素菌渣无害化处理与资源化利用工程 技术中心, 解决了抗生素行业的源头性问题。科伦抗生素全产业链的综合竞争优势已成 为业内不可撼动的默认值。

自创立以来, 科伦先后将数十亿元资金投入研发创新, 建立了国家级博士后科研工作站 和院士工作站，累计获得 13 项“国家重点新产品”称号、先后承担 12 项“重大新药创制” 科技重大项目、1 项国家科技支撑计划和 1 项国家科技援外项目支持。截至目前, 科伦 已申请专利 4000 余项, 获得专利授权 2000 余项, 在肿瘤、细菌感染、肠外营养等多个 疾病领域相继启动了 500 余项重大药物的研制, 创新专利实现海外授权, 标志着科伦的 药物研发已进入“仿制推动创新, 创新驱动未来”, 并成功进军国际市场的良性循环。

为充分利用国内外药物研究的人才和其他竞争资源, 科伦建立了以成都研究院为核心, 苏州、天津研究分院及美国研究分院为两翼的研发体系, 形成了以国内正向研发为主导, 国外技术反哺为辅助的新型研发模式，昂首进入中国药企创新能力的第一方阵。

秉持“科学求真, 伦理求善”的企业宗旨, 科伦历年为社会公益事业、光彩事业和慈善事 业提供的捐助超过一亿元人民币, 彰显出科伦的财富品质观和社会正义感, 展现出一个 优秀的民营企业在市场经济条件下健康发展的良好形象。

https://www.999.com.cn/about/intro/101002002002.html

华润三九医药股份有限公司（简称“华润三九”）是大型国有控股医药上市公司，主要从 事医药产品的研发、生产、销售及相关健康服务。上市以来, 公司多次获评中国主板上 市公司 “价值百强”、“金牛百强”企业。截止目前, 华润三九被纳入深证成份指数、中 证 500、MSCI 新兴市场指数和富时罗素（FTSE Russell）。

公司前身是 1985 年成立的深圳南方制药厂。1999 年, 由三九企业集团、深圳三九药业 股份有限公司等 5 家公司发起设立股份制公司; 2000 年 3 月 9 日，在深圳证券交易所 挂牌上市(股票代码为 000999)；2008 年，正式进入华润集团；2010 年，公司名称由“三 九医药股份有限公司”变更为“华润三九医药股份有限公司”。

华润三九主营核心业务定位于 CHC 健康消费品和 RX 处方药领域。CHC 健康消费品业 务覆盖了感冒、皮肤、胃肠、止咳、骨科、儿科等近 10 个品类，其核心产品在感冒、 胃肠、皮肤、儿科、维矿、止咳和骨科用药占据了较高的市场份额; RX 处方药业务则 聚焦消化、骨科、心脑重症、肿瘤核心领域，位居国内市场前列。

华润三九产品覆盖领域广，产品线丰富，目前拥有年销售额过亿元的品种 21 个。“999” 品牌在消费者和医药行业中均享有较高的认可度, 连续多年荣列 WPP 集团发布的“最有 价值中国品牌榜”榜单。华润三九连续多年在中国非处方药协会发布的非处方药企业综 合排名中名列前茅，999 感冒灵颗粒/胶囊连续多年荣获感冒咳嗽类（中成药）第一名。 此外，公司还有多达 10 个产品位居排行榜前列。

华润三九一直高度重视研发创新, 以公司产品“参附注射液”, “红花注射液”、“参麦注 射液”, “新泰林”, “血塞通软胶囊 (理洫王) ”为研究对象的科研项目先后四次荣获国 家科技进步二等奖。2020 年，公司围绕战略方向，持续增加研发投入，创新体系日渐 成熟。创新药物、中医中药、健康药物三个研究院在新产品立项、新产品引进、产品力 提升等领域取得积极进展; 近期还启动了华润三九与深圳湾实验室创新合作, 联合推进 抗肿瘤创新药 QBH-196 项目相关临床研究。 


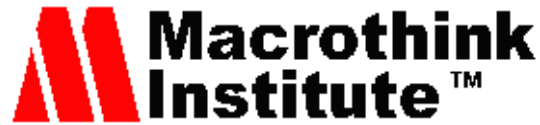

2017 年, 华润三九迈入“百亿平台”, 公司开启新的征程。在外部环境发生巨变, 医药 市场结构即将发生重大调整的背景下，华润三九充分发挥核心竞争优势，取势”中医药 “、”消费升级“、”行业整合“等发展机遇, 全力推进”洞察消费者需求, 创新和升级产品 “等系列战略举措, 致力打造创新驱动型企业, 以创新引领“高质量发展“。2018 年、2019 年, 公司业绩取得持续增长, 分别实现营业收入 134.28 亿元、147.02 亿元。2020 年, 公司克服疫情影响, 加速创新转型, 努力保持业务稳定, 实现营业收入 136.37 亿元, 净利润 15.97 亿元。

面向末来, 华润三九在“关爱大众健康, 共创美好生活”使命引领下, 朝着中国“大众医 药健康产业的引领者”的目标, 创新运用中西医科学技术, 专注高质量医药健康产品创 新研发和智能制造, 服务中国家庭每一位成员, 致力于成为中国医药健康第一品牌。

http://www.pharm.com.cn/gaikuang.html

天津医药集团是一家国有大型综合性制药集团, 其前身为成立于 1979 年的天津市医药 管理局。经过近 40 年的发展, 现已发展成以绿色中药、化学原料药、化学制剂与生物 药、特色医疗器械、现代商业物流五大板块为主体, 科研、生产、商业销售一体化运作, 拥有 180 多家企业, 控股中新药业、天药股份、力生制药三家上市公司和迈达科技一家 新三板上市公司, 与葛兰素史克、大冢、维克多等跨国知名制药公司合作组建合资企业 10 余家。集团主要经济指标位居中国医药行业前列, 连续多年入选中国企业 500 强、 中国医药工业百强。

集团产品资源丰富, 在产产品 1300 余种, 涵盖中药、化药、生物疫苗、医疗器械等多 个门类, 皮质激素原料药产能位居世界前列, 药用氨基酸原料产销量国内领先, 速效救 心丸、寿比山、京万红软膏、通脉养心丸、尤卓尔等一大批享有广泛知名度和美誉度的 “大品种”远销海内外。集团拥有“达仁堂”、“隆顺榕”、“乐仁堂”等 6 家中华老字号, “双 燕”、“松柏”、“生化”等 14 个中国驰名商标, 总数位居全国医药行业前茅。达仁堂清宫 寿桃丸等四项传统制作技艺入选国家级非物质文化遗产名录。

集团实施创新驱动, 坚持自主创新、引进消化吸收、产学研相结合的研发思路, 形成了 以 1 个国家级药物研发机构——津药物研究院、2 个国家级企业技术中心、18 个市级 企业技术中心组成的科技创新体系, 培育了一支由工程院院士领衔、各学科带头人齐备、 高素质人才云集的科技研发队伍, 构建了开发一代、生产一代、储备一代、预研一代的 科技创新梯次开发格局，科研实力持续增强，累计荣获国家科技进步一、二等奖 7 项， 并获中国专利优秀奖, 旗下多家企业被认定为国家创新型企业、国家技术创新示范企业。

新时代, 新气象, 新作为。天津医药集团将不忘初心, 牢记使命, 坚持创新引领, 贯彻 “三大主业、五大板块+两大领域”的战略定位, 继续瞄准国际先进水平, 着力实施大品 种和资本运营战略, 延伸优势、延长链条, 努力打造最具创新力和竞争力的中国医药新 领军企业, 为人类健康事业做出更大贡献。

http://m.qilu-pharma.com/intro/1.html

根植齐鲁 家国天下

齐鲁制药以维护人类健康为宗旨, 以满足社会需求为己任, 以先进的科学技术为依托, 致力于研制开发治疗常见病、多发病及其它多种严重危害人类健康疾病的药物。 
公司总部位于山东省济南市, 是中国大型综合性现代制药企业, 专业从事治疗肿瘤、心 脑血管、抗感染、精神系统、神经系统、眼科疾病的制剂及其原料药的研制、生产与销 售。

公司始终坚持创新发展战略, 以市场需求为核心, 以产品创新为先导, 广泛拓展国内外 科研开发合作, 注重人才的引进与培养, 建有一支高素质的科研队伍, 具备专业而高效 的研发能力, 已先后研制成功了近百个国家级新药, 为公司未来的发展建立了合理的在 研产品线, 多项研究被评为国家、省级科技进步奖，并创造了良好的社会效益。

公司建有制剂、化学合成、生物技术、抗生素发酵等十大生产基地以及现代化的生产车 间, 全自动生产线和其他主要生产设备及检测仪器均购自于世界主要专业制药设备制造 商, 抗生素类原料药、头孢类原料药、抗肿瘤类原料药等数个产品已具有国内乃至世界 领先的生产能力和生产水平。

公司建设了严格规范的质量控制机构和完善的质量保证体系, 是首批国家食品药品监督 管理局 GMP 认证企业。其中非无菌原料药 (发酵、化学合成)、无菌原料药及多种制 剂通过了美国、欧盟、澳大利亚、英国、南非以及其它国家和地区药品监管机构的认证。

公司的产品结构科学完整, 已上市产品达 270 余种, 具有治疗领域广、产品系列化特点。 凭借过硬的产品质量、全心全意为客户的服务宗旨, 在医药领域树立了齐鲁品牌, 拥有 遍布全国各大省市, 远销北美、欧盟、日本、澳大利亚等地的世界级销售网络, 以卓越 的服务向中国和世界呈现着完全可以信赖的真诚。

“大医精诚, 家国天下”, 公司凝练出独具齐鲁特色的企业文化, 积极倡导“有国有厂才 有我们幸福的家” 的齐鲁精神, 实现了员工与企业的共同成长。在快速发展的同时, 切 实履行各项社会责任, 扶危救困, 奉献爱心, 以辉煌的成就、傲人的气魄展示了中国民 族医药企业的发展与腾飞。

http://www.zzpzh.com/gsjs/index_12.aspx

公司介绍

漳州片仔癀药业股份有限公司是以医药制造、研发为主业的国家技术创新示范企业、中 华老字号企业，现市值超 1500 亿。拥有 1 家研究院、35 家控股子公司、7 家参股公司。 经营 6 大品类、 470 多个产品系列。在全国 7 个省、直辖市建立 23 个科研、生产和药 材基地。国宝名药片仔癀, 为国家中药一级保护品种, 中成药单品种出口连续多年位居 中国第一，成“海丝”路上“中国符号”。

近几年来，公司积极践行“健康中国”国家战略，传承精华、守正创新，实施“一核两翼” 大健康产业发展战略, 推动片仔癀现代化、产业化、国际化, 在高质量发展中, 不断迈 上新高度。

核心产品

国宝名药片仔癀, 为国家中药一级保护品种, 处方和工艺受国家保护, 传统制作技艺列 入国家非遗名录，单品种出口连续多年位居中国中成药外贸单品种出口前列，成“海丝” 路上“中国符号”。

片仔癀荣誉 
公司荣膺中国主板上市公司价值百强、全国文明单位、全国质量标杆、国家级“绿色工 厂”、全国慈善会爱心企业、福建省工业企业质量标杆、福建省劳动关系和谐企业、福 建省节水型企等 20 多项称号, 被授予 (第六届) 福建省政府质量奖。企业技术中心通 过国家评定, 研发实力居中国中药研发实力前 10 强 (列第 7 位), 片仔癀连续多年居“中 药大品种科技竞争力”排行榜清热解毒领域第一名。品牌连续六年获评“健康中国”肝胆 用药第一品牌, 以 566.96 亿列《2020 年中国最具价值品牌 100 强》第 55 位, 居 2020 年 胡润品牌榜医疗健康行业第 1 位。

经营业绩

2020 年，公司实现营收 65.07 亿元，比增 $13.72 \%$; 利润总额 19.82 亿元，比增 $20.53 \%$; 净利润 16.94 亿元, 比增 $22.12 \%$; 上缴税收 8.7 亿元, 比增 $29.33 \%$, 再创同期历史新高。 全球投行 Torreya 发布 2020 年《全球 1000 强药企报告》, 公司排名从 2019 年的第 80 位上升至第 49 位, 位居中国前 10 强。

公司将始终坚持以习近平新时代中国特色社会主义思想为指导, 认真贯彻落实习近平总 书记关于发展传统中医药的一系列重要指示精神, 全面推进企业高质量发展超越, 为健 康中国 2030 行动、为推进福建省医药产业的发展贡献力量。

https://www.yangzijiang.com/\#/chinese/groupPanorama/introduce

千百年来, 长江奔腾不息, 以无私的情怀哺育着华夏生灵。长江为魂, 苍生为念, 孕育 了位于长江之畔的扬子江药业集团, 赋予了扬子江人“求索进取, 护佑众生”的使命追求。

扬子江药业集团创建于 1971 年，是科技部命名的全国首批创新型企业。集团总部位于 江苏省泰州市，现有员工 16000 余人，旗下 20 多家成员公司分布泰州、北京、上海、 南京、广州、成都、苏州、常州等地; 营销网络覆盖全国各省、市、自治区。集团践行 “高质 惠民 创新 至善”的核心价值观, 致力向社会提供优质高效的药品和健康服务。 继 2016 年品牌强度、品牌价值双双名列中国品牌价值榜生物医药板块第 1 名后, 2020 年, 扬子江药业集团以品牌强度 945 分, 品牌价值 505.95 亿元的优异成绩再次夺得中 国品牌价值榜医药健康板块品牌强度、品牌价值双第一。还相继荣获“欧洲质量奖”、“全 球卓越绩效奖”（世界级）、“亚洲质量创新奖”、“全国重合同守信用企业”、“全国文明 单位”等称号。

集团贯彻“质量第一、效益优先”发展方针, 拥有 4 个国家级创新研发平台, 获 3 项国家 科技进步二等奖, 5 个中药材进入欧洲药典标准。大力弘扬工匠精神, 自 2005 年以来, 蝉联全国医药行业 QC 成果评比一等奖总数“十六连冠”; 2015-2020 年获得 24 个国际 QC 金奖， 2014 年-2019 年，扬子江连续 6 年位居中国医药工业企业百强榜第 1 名。扬 子江被中国食品药品检定研究院、江苏省食品药品监督管理局等指定为“实训基地”。

扬子江水哺育中华, 扬子江药造福华夏。在党的十九大精神指引下, 扬子江药业持续不 断深化供给侧结构性改革, 实施大健康产业战略, 不忘初心, 牢记使命, 砥砺奋进, 立 志成为健康领域最受尊敬的世界一流制药企业。 


\section{Copyright Disclaimer}

Copyright for this article is retained by the author(s), with first publication rights granted to the journal.

This is an open-access article distributed under the terms and conditions of the Creative Commons Attribution license (http://creativecommons.org/licenses/by/4.0/). 